Article

\title{
Theodicies as Failures of Recognition
}

\author{
Sari Kivistö ${ }^{1}$ and Sami Pihlström ${ }^{2, *}$ \\ 1 Faculty of Communication Sciences, University of Tampere, Tampere 33014, Finland; sari.kivisto@uta.fi \\ 2 Faculty of Theology, University of Helsinki, Helsinki 00014, Finland \\ * Correspondence: sami.pihlstrom@helsinki.fi; Tel.: +358-40-5015535
}

Received: 10 October 2017; Accepted: 28 October 2017; Published: 1 November 2017

\begin{abstract}
This paper examines the ethical failure of theodicies by integrating the perspectives of philosophical argumentation and literary reading and analysis. The paper consists of two main parts. In the first part, we propose an ethical critique of metaphysical realism by analyzing its inability to recognize the perspectival plurality and diversity of suffering. As theodicies seek to explain how an omnipotent, omniscient, and absolutely benevolent God could allow the world to contain evil and suffering, it can be argued that metaphysical realism-i.e., the thesis that the world possesses its own fundamental structure independently of human perspectives of conceptualization and inquiryis a problematic starting point of theodicism. We examine the failure of recognition of others' suffering inherent in theodicies as a failure based on the search for an overall reductive and objectifying picture (a "God's-Eye View") that is constitutive of metaphysical realism. The second part of the paper shows why we should include insights from imaginative literature in our attempts to understand the recognition failures of theodicies. Emphasizing the literary, philosophical, and theological relevance of various modern rewritings of the Book of Job, which has been a crucially important sub-text for many later literary works in which the protagonists render a particular kind of human experience-unmerited suffering-we turn more closely to some literary examples, such as Joseph Roth's novels Hiob and Die Rebellion. The tensions that are created around the moral controversy of the experiences of injustice and suffering and the human and religious reasoning and justification of violence are examined. The ambiguous ending of Hiob that adds an apparently hopeful and almost fairytale-like redemption to the story plays a crucial role in the interpretation provided in the paper. By analyzing some literary examples and their relation to the literary Job tradition, the recognition-failures of theodicist attempts to provide meaning into suffering-attempts based on metaphysical realism, as argued in the first part of the paper-are highlighted. Finally, we also critically consider the charge that theodicism could only be theoretically formulated and argue that a sharp distinction between theory and practice in this area is itself an act of non-recognition, or a failure to recognize suffering.
\end{abstract}

Keywords: suffering; theodicy; theodicism; antitheodicy; antitheodicism; realism; metaphysical realism; recognition; acknowledgment; literature; the Book of Job; Roth, Joseph

\section{Introduction}

Theodicies, seeking to justify "the ways of God to man," attempt to view human suffering from an overall metaphysical and/or theological perspective. From such a perspective, all apparently unnecessary and meaningless evil and suffering there seems to be in the world we live in is rendered in some sense "meaningful" or at least necessary for the overall goodness of the harmonious world system. While theodicies have been proposed by both classical and contemporary thinkers throughout the history of theistic thought (and there are, arguably, also secular theodicies available in the discussion), there is a growing tradition of moral criticism of theodicies drawing attention to their arguably striking insensitivity to human suffering (see, e.g., Betenson 2016). This tradition deserves further philosophical 
scrutiny, but it also needs to be carefully examined what the peculiar insensitivity typical of theodicies actually consists of.

Therefore, a key aim of this paper is to offer an ethical critique of metaphysical realism by analyzing its inability to recognize the perspectival plurality and diversity of suffering, interpreting the failure of recognition of others' suffering inherent in theodicies as a failure based on the search for an overall reductive and objectifying picture (a "God's-Eye View") arguably constitutive of metaphysical realism. In addition to engaging theodicies and their metaphysically realist background assumptions by philosophical argument and criticism, we will show why it is vital to include insights from imaginative literature in serious attempts to understand the recognition failures of theodicies. Emphasizing the literary, philosophical, and theological relevance of various modern rewritings of the Book of Job, a crucially important sub-text for many later literary works addressing unmerited suffering, our paper more closely analyzes some literary examples, such as Joseph Roth's novels Hiob and Die Rebellion that take a critical stand on any overarching perspective on individual suffering.

Arguing that theodicism typically (though not strictly speaking logically) presupposes metaphysical realism, as both assume the availability of a "God's-Eye View" theory of why there is evil and suffering (i.e., God's reasons for allowing the world to contain apparently meaningless and unnecessary evil and suffering on the massive scale familiar to us on a daily basis), we will not only argue against theodicism by criticizing its background assumptions but also (indirectly) against metaphysical realism itself by providing reasons for rejecting its (typical) consequence, theodicism. Metaphysical realism and theodicism will then ultimately collapse hand in hand. However, we should also to observe that this collapse does not lead to a rejection of realism tout court. Rather, antitheodicism - the view that abandons the entire project of theodicy, as will be explained in more detail below-needs a moderately realist understanding of humanly speaking objective reality and truth, but it is precisely the human dimension of this need that is not adequately available within metaphysical realism.

Let us start with some conceptual preliminaries made explicit in some of our earlier work, especially Kantian Antitheodicy (Kivistö and Pihlström 2016). We propose to define theodicy and theodicism simply with reference to the attempt to provide a justification for apparently senseless (meaningless, absurd) suffering. Generally, we may say that theodicies seek a justification, legitimation, and/or excusing of an omnipotent, omniscient and absolutely benevolent God's allowing the world (His creation) to contain evil and for allowing humans and other sentient beings to suffer. Classical formulations of theodicies can be found, for example, in Augustine's and his numerous followers' appeals to God's having created human beings with freed will as the reason why there is evil, and in G.W. Leibniz's position, formulated in his famous Théodicée (1710), according to which God could not have created any better world than the one that he, as omnipotent and absolutely good, did create; according to this Leibnizian theodicy, we live in "the best possible world," and while there is indeed some evil there, it is necessary for the overall good. Leibnizian theodicies are good examples of purely metaphysical attempts to explain the place of evil within the absolute divine harmony of the world; it does not aim at a moral justification of God's allowing suffering but at a metaphysical excuse explaining why even the best possible world may include some evil—or even quite a bit.

More recent examples of theodicies include attempts to revive "free will theodicies" and "soul-making theodicies" by major philosophers of religion such as Richard Swinburne and John Hick. Classical atheist arguments based on the problem of evil and suffering have, in turn, been presented by philosophers like David Hume and J.L. Mackie, while several contemporary thinkers have proposed "defenses" intended as more moderate than theodicies proper, suggesting that there is a possible world in which God has good reasons to create and maintain a world in which humans and other sentient beings suffer horribly, without necessarily claiming that possible world to be actual, or claiming that we would be able to know God's actual reasons (cf., e.g., Van Inwagen 2006).

Now, by "theodicism," we may refer to all those attempts to deal with the problem of evil and suffering that regard theodicy as a desideratum of an acceptable theistic position, irrespective of 
whether they end up defending theism or rejecting it. The theodicist can, then, very well be an atheist, insofar as they conclude that God does not exist (or probably does not exist, or that there is no justification for the belief that God exists) precisely because the theodicist desideratum cannot be fulfilled. Also those who propose a mere "defense" —instead of a theodicy proper—can be regarded as theodicists in the sense that they also seek to defend God and account for God's justice by arguing that, for all we know, God could have ethically acceptable reasons to allow the world to contain evil and suffering, even the kind of truly horrible evil and suffering familiar to anyone with adequate moral sensitivities in the world we live in. By "antitheodicism," in contrast, we may mean the rejection of any such, or indeed any, theodicies, or better, of the very project of delivering a theodicy or the attitude of encouraging or requiring engagement in such a project.

Theodicism and evidentialism - that is, the view that the rational acceptability of religious beliefs should be evaluated on the basis of the (religiously neutral) evidence that can be presented for and against them-are closely connected. As mainstream philosophy of religion today is (albeit with significant exceptions) relatively strongly evidentialist, at least in a broad sense, it comes as no surprise that it is also often strongly theodicist when dealing with the problem of evil and suffering. Accordingly, the existence of evil and suffering is in most cases formulated as an empirical premise challenging the theistic belief in an argumentative exchange searching evidence in support of, or against, the theistic hypothesis. This is so irrespective of whether the problem of evil is regarded as a logical or as an evidential problem (cf. Rowe 2001). The theistic goal is to respond to the atheists' "argument from evil." Just like theodicism is a normative view according to which any rationally acceptable theism ought to formulate a theodicy (or at least take steps toward the direction of a theodicy by formulating a more moderate "defense"), evidentialism is a normative epistemological view according to which any rationally acceptable theism ought to be defended by means of evidence, or rational considerations more generally. Theodicism is, then, a specific dimension of evidentialism: it tries to tell us how we should discuss the problem of evil when evil is regarded as a piece of evidence against theism that the theist needs to deal with.

A philosophical critique of theodicism is, therefore, a critique of the entire argument from evil and its use in both theistic and atheistic discourse. In this sense, again, our considerations in this essay will have a metaphilosophical dimension. It seems to us-though we cannot defend this view here (but cf. Kivistö and Pihlström 2016)—that the philosophically most interesting and profound disagreement lies not between theism and atheism or between religious believers and nonbelievers, but between the overall ethical and religious attitudes to suffering (and, hence, to reality generally) adopted by theodicism and antitheodicism.

While the link between theodicism and evidentialism seems to be relatively clear, the relation between theodicism and realism, especially metaphysical realism, has not been studied in any great detail in previous literature. We will try to argue that metaphysical realism is one of the most problematic background assumptions of theodicism - just as it is a problematic starting point in many other philosophical areas of inquiry, including various recent theories of the self, of death, and related matters (see Pihlström 2016). By metaphysical realism we may here simply mean the view that the world possesses its own fundamental ontological structure independently of our perspectives of conceptualization and inquiry and can, therefore, in principle be truly and completely described from an absolute standpoint (i.e., a "view from nowhere," or a "God's-Eye View," as it were). Metaphysical realism is, in fact, a conjunction of various more specific forms of realism, especially ontological, semantic, and epistemological.

After these introductory remarks and conceptual preliminaries, we may first turn to an analysis of the philosophical commitment to metaphysical realism as the background assumption of theodicism and then to interpretations of some literary manifestations of these ideas. As will be explained in the concluding section, our defense of antitheodicism is also in an important sense humanistic - and we may hope that this emphasis on humanism is (implicitly) highlighted by the heavy role played by literary reading and analysis in our argument. 


\section{Theodicy and Metaphysical Realism: Against Reductive Objectification}

Let us briefly consider an example explicitly referring to the deep connection between realism and theodicism that we have only in a sketchy and introductory way invoked above. Peter Byrne (2003) argues that realism is needed in the philosophy of religion partly, or even primarily, because responding to the problem of evil by delivering a theodicy presupposes realism. Byrne suggests that theism needs to incorporate a "generic offer of a theodicy," and this requires a realistic conception of the divinity conjoined with moral teleology and a conception of a "final good" of human life (Byrne 2003, p. vii). Byrne's basic characterization of realism says that "the governing intent behind the concept of God is to refer to an extra-mental, extra-mundane, transcendent entity" (Byrne 2003, p. 6). While theodicies may not be explicitly invoked in realism discussions in the philosophy of religion, Byrne seems to maintain that the entire realism debate is largely motivated by the need to provide a theodicy-that is, by theodicism (as we have called it above):

The need or problem is that of finding a response to evil. In particular, [religions] arise out of the human perception that the apparent order of the world around them is not a moral order; it is indifferent to the achievement of human happiness and the realisation of human goodness; it presents itself as blind and indifferent to justice. It is the job of a religion on this account to offer human beings a theodicy. (Byrne 2003, p. 17)

It is prima facie surprising to hear that religions should offer us theodicies, as one might think that this is the job of theology (or perhaps of the philosophy of religion) rather than religion itself. Be that as it may, Byrne insists that "a religion is any set of symbols (and associated actions, attitudes, feelings and experiences) providing human beings with a solution to evil by way of a theodicy"; more generally, religion is "that propensity in human beings (however grounded) to respond to evil by seeking the kind of meaning [ ... ] associated with the enterprise of theodicy" (Byrne 2003, p. 18). Realism is needed for religion, because providing a theodicy invokes a "moral and providential causality in the world" transcending natural and human powers as well as a relational conception of the human good as "a matter of living in right relation to the source of the providential, moral order postulated as response to evil" (Byrne 2003, p. 18). The program of defending realism in the philosophy of religion thus includes, Byrne maintains, a critique of the very coherence of antirealist views of good and evil. ${ }^{1}$

Antitheodicism argues that the kind of theodicies Byrne and many other philosophers of religion defend-theodicies either seeking to philosophically justify or legitimize God's allowing apparently unnecessary and meaningless evil and suffering, or offering some secular proxy for this traditional theological project-amount to a colossal ethical failure to recognize the suffering other and the utter pointlessness of their suffering. Instead of taking others' suffering morally seriously, theodicies (as well as the only allegedly more moderate "defenses") arguably instrumentalize suffering in the service of some postulated or imagined overall good. Such an ethical argument for antitheodicism, focusing on the moral need to appropriately recognize the reality of suffering, or to take evil seriously, can draw from various sources, including William James's (1907) pragmatism, Wittgensteinian philosophy of religion (e.g., Phillips 2004), as well as post-Holocaust Jewish moral reflection exemplified by Emmanuel Levinas (2006) ethics of otherness, all of which can be interpreted as fundamentally Kantian formulations of antitheodicism (Kivistö and Pihlström 2016, chps. 3-5). These antitheodicisms are,

1 On the other hand, atheist criticisms of theism, based on the argument from evil (e.g., J.L. Mackie's well-known logical argument), have also been attacked because of their commitment to axiological or moral realism, a standard assumption in the theodicy discourse. Consider especially (Carson 2007). Carson criticizes Mackie's problematic combination of moral error theory and assumption of moral realism in his formulation of the logical problem of evil. Mackie, a famous critic of moral realism and theism, seems to assume the truth of moral realism in his discussion of the problem of evil by (arguably) assuming that pain and suffering are mind-independently bad or evil. The issue, then, concerns the mutual (in)coherence of Mackie's views on ethics and religion (or atheism). This argument obviously targets Mackie in an ad hominem fashion, but it may teach a more general lesson of the need to consider the coherence among the various assumptions concerning realism and antirealism we make in different areas of philosophical inquiry. 
we may suggest, "Kantian" not because they would necessarily explicitly refer to Immanuel Kant's own criticism of theodicies (or the Kantian theory of "radical evil," for instance) but because (i) their moral criticism of speculative metaphysics can (implicitly) be traced back to Kant's 1791 "Theodicy Essay" and its rejection of theodicies as violations of the limits of human reason (based on the general approach of Kantian critical philosophy), and (ii) they arguably seek to show that theodicies violate the necessary conditions for the possibility of adopting a moral perspective on the world and other human beings. (For other influential antitheodicist considerations in the contemporary discourse on evil, see, e.g., Bernstein 2002; Neiman 2002.)

Antitheodicists are usually not only non-evidentialists but also non-realists (at least in the sense of rejecting metaphysical realism), though not for that reason necessarily antirealists. This is so whether they start from Wittgensteinianism (e.g., Phillips), pragmatism (e.g., James), or Jewish post-Holocaust ethics (e.g., Levinas). ${ }^{2}$ For example, Levinas seems to maintain that the metaphysically realist attempt to occupy a totalizing God's-Eye View on others' suffering is the source of theodicist immorality. ${ }^{3}$ Phillips, in turn, regards transcendent theistic accounts of moral goodness as morally corrupting, as they do not acknowledge the "pointlessness" of evil. Byrne's (2003, pp. 132-35) metaphysical moral teleology and his theodicism based on metaphysical realism are thus diametrically opposed to Phillips's position. The bone of contention seems to be that while for Byrne goodness ultimately serves cosmic divine purposes, for Phillips goodness is non-teleological, "purposeless" (just like evil, analogously, is pointless) (Byrne 2003, p. 134). Metaphysical realism, then, is the key issue dividing these two thinkers and in its way explaining their divergence regarding theodicies. Furthermore, it can be argued that William James's (1907) pragmatist criticism of the "absolute" (and Hegelian monistic idealism, for him the paradigmatic form of metaphysical realism) is also primarily ethical; the metaphysical critique is based on the ethical unacceptability of the absolute yielding an irresolvable theodicy problem.

Why exactly is realism a key issue here? We propose that this is because metaphysical realism, at least typically if not inevitably, reductively objectifies - that is, tends to view as mere objects in the world-something that really cannot (and ethically ought not to) be viewed as mere objects among others "out there" in the mind-, practice-, and discourse-independent world: first of all God (easily, albeit perhaps not inevitably, leading to a kind of simplistic anthropomorphism) as well as, secondly, others' suffering (reduced into mere processes in the objective empirical world) ${ }^{4}{ }^{4}$ and hence also, thirdly, otherness itself. Such objectifications are in striking contrast with Levinas, in particular, for whom the other is more fundamental than any object-subject structure-and with (e.g., Jamesian) pragmatism, which also refuses to postulate a pre-structured reality independently of human valuational pursuits and practices. The crucial point here is that by reductively objectifying things that are beyond objectification, theodicism based on metaphysical realism also overlooks the diversity and perspectival nature of both suffering and human beings' individual (religious or non-religious) responses to suffering. ${ }^{5}$ In other words, metaphysical realism and the theodicism based upon it are essentially detached views when it comes to responding to others' suffering; instead of being involved and engaged,

2 These different antitheodicisms are argued to not only belong to the Kantian tradition of antitheodicism but also to be indebted to Kant's (1791, Kant 1983) reading of the Book of Job (emphasizing Job's sincerity and truthfulness) in Kivistö and Pihlström 2016.

3 We are indebted to Panu-Matti Pöykkö's still mostly unpublished work on this feature of Levinas's thought.

4 Similarly, we may say that metaphysical realism objectifies human death and mortality into a mere empirical and factual events and states in the world, while a more Kantian-oriented transcendental approach to human mortality seeks to understand death as a limit phenomenon and horizon of life without which no worldly events would be humanly possible. Cf. (Pihlström 2016).

5 By diversity we here primarily mean the immense individual diversity of human beings' experiences of suffering and their responses to and ways of dealing with that suffering. Thus, we do not primarily intend this in the sense of social or cultural diversity, but of course such diverse backgrounds also crucially influence the ways in which individuals experience and respond to their experiences of suffering. 
the theodicist relies on metaphysical realism in seeking to maintain a "view from nowhere" that puts suffering in its proper place in the overall clean and well-lighted picture of the universe.

From a Kantian point of view, we may say that the basic problem with metaphysical realism and its applications in theodicism - and everywhere else-is the tendency to seek a theocentric perspective, which is necessarily unavailable to us (or better, not just unavailable but something the pursuit of which remains humanly incoherent). It is arguably also an ethically problematic goal even to try to reach it precisely because it is ethically problematic to reduce others' experiences of suffering into mere objective processes and events in the world taken to be independent of our ethical acknowledgment of suffering in its meaninglessness irreducible to any alleged theodicist meaningfulness. A related problem in metaphysical realism is the attempt to make metaphysics prior to ethics, whereas the kind of critique of metaphysical realism and theodicism advanced here makes a meta-level case for the profound entanglement of these two areas of philosophy. However, the entanglement of ethics with metaphysics cannot itself be regarded as an objective fact in the world (based on metaphysical realism) but must be considered a feature of the human lifeworld and practices. It is in terms of such entanglement that we must see ourselves, and the world we live in, when we take seriously our irreducibly ethical pursuit of responding to suffering.

An antitheodicist ethics of acknowledgment thus cannot be based on any objectifying metaphysical realism; yet, it must maintain an ordinary notion of objective truth needed for the requirement of sincerity fundamental to Kantian antitheodicism. ${ }^{6}$ Something like an ordinary concept of truth—not necessarily requiring any sophisticated philosophical elaboration-is needed simply in order for someone who has undergone experiences of suffering to be able to acknowledge the fact that that suffering actually took place; hence, such a notion of truth is also necessary for our antitheodicist purposes, because the antitheodicist must be able to argue that there is a sense in which theodicies with their "God's-Eye View" narrative structures overlook or neglect the truth about what really happened to an individual sufferer or how they experienced their suffering. Failure of acknowledgment is the crucial ethical failure in theodicist attempts to justify "the ways of God to man"; this is the antitheodicist's fundamental charge against theodicism. ${ }^{7}$ These thoughts also lead us to appreciate why there should, and indeed can, be no argument from evil. This is precisely because arguing from evil, or responding to such arguments theodicistically, already presupposes metaphysical realism (and evidentialism), objectifying the very experiences of suffering that must not be objectified. (Note, however, that the presupposing relation can be bilateral: according to Byrne realism itself presupposes, as we saw, the project of providing a theodicy, as something that generically and essentially belongs to religions.) The very use of the empirical premise stating the reality of evil in the argument from evil—and theodicist responses to that premise and its atheist usage-insensitively objectifies as well as instrumentalizes suffering.

We should, furthermore, note that the nowadays fashionable position known as skeptical theism also problematically presupposes metaphysical realism. According to such a view, God is claimed to have (or possibly have) reasons for allowing suffering that we just do not or cannot know. The "divine hiddenness" discussion is yet another debate in contemporary philosophy of religion that is in a

6 Cf. again Kivistö and Pihlström 2016, especially the analysis of the exchange between James Conant and Richard Rorty on George Orwell's Nineteen Eighty-Four (chp. 5).

7 A more comprehensive examination of these issues would also critically explore the relation between recognition and acknowledgment. Recognition focuses on cognition (knowing), and is hence, arguably, ultimately based on metaphysical realism, while acknowledgment focuses not on knowing but on acknowledging, in a non-metaphysically-realist way. However, this idea needs considerable further development. (On the history of the issue of recognition in religion and theology, see Saarinen 2016.) Furthermore, the need to appeal to the "truth" of individual experiences of suffering in antitheodicist argumentation does not entail the subjectivist or relativist view that each individual account of such experiences would be as valuable as any other and that critical discussion across such perspectival interpretations of suffering would be impossible. Such discussion may be difficult, but certainly antitheodicism by no means precludes the possibility of acknowledging also the occasional failures of sufferers' own interpretations of their situations. On the other hand, such interpretive disagreements must always, for ethical reasons, be approached with utmost sensitivity. 
questionable manner based on metaphysical realism. All these issues concerning the relation between God, human beings, and the world objectify God as well as otherness, presupposing that we can adopt a theocentric perspective on these matters, even though they are deeply human problems to which there is only a finite anthropocentric perspective available for us, amidst our ethico-religious human practices. Even the skeptical theist assumes that in principle a theocentric perspective could and should be available, while it merely de facto contingently is not. When the divine hiddenness issue is raised as a purely intellectual puzzle allegedly external to religious life itself, it differs crucially from the genuinely religious and/or existential anxiety associated with real-life experiences of the hiddenness of God (which may or may not lead to one's losing one's religion). ${ }^{8}$

It should be clear at this point that we believe metaphysical realism to be strikingly inadequate for exploring experiences and possibilities like this. Experiences of divine hiddenness and meaninglessness require an entirely different philosophical framework to be adequately addressed, and such a framework is unavailable in metaphysical realism. The purpose of this paper is not to articulate such an antitheodicist framework in any detail, but we have earlier (Kivistö and Pihlström 2016) argued that antitheodicisms continuing the Kantian tradition-including above-mentioned approaches such as Jamesian pragmatism, Wittgensteinian philosophy of religion, and Levinasian post-Holocaust ethics of otherness-are worth developing further in this regard.

\section{Literary Examples of Unmerited Suffering: Modern Treatments of Job}

We will now move on to a consideration of fictional literature as integral to our argument criticizing both theodicism and metaphysical realism as its presupposition. Any literary examination of antitheodicism must begin from the Book of Job, which is the traditional key text of useless and unmerited suffering. Job objects to theodicies that would explain his suffering in terms of just punishments for bad deeds, since in his own view he had never committed any crimes meriting such suffering. Job's friends, in turn, give rational explanations to his unwarranted suffering, thus representing false theodicy, that is, official and normative views of faith that try to justify God's reasons despite Job's concrete individual experience of the world. The friends offer traditional religious means of repentance and self-examination to heal Job's distress, although these interpretations of his condition actually increase his suffering by falsely attributing guilt to him.

Especially after the Second World War, critics have emphasized that narrative means can be ethically problematic in trying to make sense of individual suffering. Relying on this interpretative approach, Carol A. Newsom (2009) has analyzed how the friends falsely attempt to reduce Job's experience and also God's reasons to larger narrative structures, which would explain the causes and consequences of Job's unjust suffering. Newsom points out that in trying to integrate Job's experience of meaningless suffering by their traditional narrative patterns the friends perform an unethical act, since these patterns (e.g., stories of the bad fate of the wicked or the hope of the virtuous) fail to do justice to Job's present and particular situation and deny his own considerations

8 As against the mainstream analytic divine hiddenness discussion today, we may (again joining Wittgensteinian philosophers like Phillips) suggest that the experience of God's hiding, or being unavailable to human beings in prayer, for instance, is internal to a religious way of life, challenging the life and thought of a person engaging in religion from within-just as we may say that experiences of meaningless evil and suffering could be internal to religious life in an analogous way. Experiences of divine hiddenness could also challenge a non-believer, or an agnostic, to become more deeply engaged with an "awareness of what is missing" (see Habermas 2010). Indeed, it is possible that this is the form of religious experience available to a secular modern person, an experience possibly arising from a consideration of the problem of evil and suffering: it does not seem to be the case that God is really in charge of the world or history. At the meta-level, a secular yet religiously sensitive educated person might actually long for the possibility of (still) being part of the kind of meaningfulness or significance (internally belonging to a genuinely religious form of life) that makes possible the religiously relevant meaninglessness of a religiously experienced divine hiddenness. This meta-level question of meaningfulness and meaninglessness (which includes the ethical requirement of adequately acknowledging others' experiences of meaninglessness, especially the meaninglessness of suffering) is presumably the closest that reflective secular persons today can get to religious experience-and an awareness of the significance of the problem of evil and suffering, antitheodicistically formulated, might be crucial in reaching this meta-level acknowledgment. 
of his condition. The friends suggest that by praying Job would attain an order in his affliction, but a meaningful moral order is precisely what Job is fundamentally lacking in his suffering. He insists that his suffering cannot be reduced to any meaningful storylines with initial causes and their effects, or relieved by therapeutic prayers or by the friends' consolations (cf. Job 16: 2-5). Nor can his suffering, as Newsom observes, be explained with reference to such conventional positive patterns as those of hope, transformation, or survival, which would help interpret Job's situation in the light of a meaningful whole, where the sense of wholeness and purposefulness is happily attained at the end of the story. Job's friends thus create conventional cultural patterns to present claims about the moral order and coherence of the world, but their fabrications are condemned by Job (as well as by Kant in his later theodicy essay: see again Kant 1983) ${ }^{9}$. Suffering does not take place in a world that is purposeful, ordered and teleological, since the lived experience denies such order and symmetry. As Newsom claims, Job questions the narratability of his violent experience. If modern philosophical terms had been available to Job, he might have resisted the metaphysical realism-the commitment to a "God's-Eye View" picture of a coherent world—that can be found at the background of the friends' theodicist suggestions.

The rejection of theodicies reappears frequently throughout modern literature and already before the Holocaust. In modern rewritings of Job, individual freedom is set against one or another overwhelming power of necessity crushing the individual agent and his or her freedom. What is also common to these figures is that none of them quietly accepts this condition, but they all ask for divine justice and soon also fight against the unjust forces around them. Like Job, who is an archetype of both unnecessary suffering and resistance, they object to theodicies that would explain their suffering in terms of just punishments for bad deeds, since in their own view they have never committed any crimes meriting such suffering. Among the famous literary characters who share this less patient basic reaction to suffering and turn to a rebellion against God is Franz Kafka's Josef K., who in Der Prozess (1925; see Kafka 1955) undergoes an experience, a mysterious condemnation, for which significance is hard to discover. Josef $\mathrm{K}$. is arrested without having done anything wrong (etwas Böses), and he remains equally steadfast of his innocence as Job. Instead of accepting the existence of a moral balance in the world, both Job and Kafka's Josef K. start to challenge the idea of divine justice and soon also rail against God (or other powerful forces surrounding them). The protagonists' experience suggests that there is no moral order or harmony in the world unless humans themselves start to struggle for a morally better world. These literary works challenge the human project of making sense of suffering by providing meaning to suffering, and thus crucially develop the idea of antitheodicy that rejects such attempts of justification, suggesting that the problem of evil and disproportional suffering cannot be solved by theoretical reason or by appealing to such simple narrative or doctrinal patterns as punishment or reward.

In Kafka's novel God does not address man; the absence of the dialogue between humanity and God is the most agonizing feature in the novel. When Josef K. asks where the Judge is who could decide about his case and where the Court is that would discuss it, nothing turns up. The famous parable "Before the Law" at the end of the novel is a key passage that illustrates the human being's futile efforts to try to gain access to the Law and his repeated failure to be admitted. The parable is a metonymic illustration of the fact that Josef K. will never see the Judge or the Law he wishes to see and he is permanently left outside the doors, in the bewilderment of the meaning of his life. Thus, the story is a reversal of the Book of Job in which God does finally appear and address Job out of the storm-wind. Kafka refuses to fix meanings in any theological way and ground them in God. Josef K.'s story can be read as a mystery of human failure or a mystery of divine justice that is beyond the realm of human knowledge, but the latter view is less plausible if we read the novel in terms of

9 English translation by Allen W. Wood and George Di Giovanni in Kant, Religion and Rational Theology. Cambridge: Cambridge University Press, 1996. 
antitheodicy (as we want to suggest). The absence of any certain answers from suprahuman forces is crucial here, but we should take it as a chance given to humans, instead of reading the novel simply as a pessimistic description of the despair of a modern secular person who will no longer be able to access the unity with God. Closed doors and the overall metaphysical emptiness that characterizes the world of the novel can be relieving to humans, since they encourage us to take responsibility for our actions, instead of trying to find some official instance or a higher power to judge our doings. This is how we can interpret the oft-noted Kafkaesque silence of the gods or the hermeneutic crisis; the openness and uncertainty and the missing totalizing view are ethically significant. That there is no visible sign of divine justice discernible to human beings does not mean that the human life would be therefore meaningless. On the contrary, the very absence of such signs may be a prerequisite for us humans to live a life that is deeply ethical. Similarly, we may say that the kind of rejection of metaphysical realism that we find necessary for antitheodicism is itself an ethically invigorating metaphysical move.

Samuel Beckett's Waiting for Godot (1952, in Beckett 2006) is another obvious key text here, as it explores the questions about the unfulfilled human desire for something to turn up, for signs of higher powers, some rational basis of things or a meaningful order that would suggest that the world does not end at the borders of the self. Yet the actual experiences of the protagonists record mere rootlessness and painful suffering; they mourn their situation basically in the same way as Job, although their suffering takes a different form of stasis and timelessness. In Beckett's antitheodicist works, the very existence of a super-perspective is suggested to be fundamentally illusory; such an illusion is maintained in order to hold back the suspicion that the world in which humans suffer is completely meaningless and that human beings are there alone. The protagonists would like to see evidence of transcendent powers in the smallest of events, and they would love to submit themselves to something larger than themselves, some extra-mental creature, but the mysterious Godot remains entirely absent, and keeping his distance Godot is merely produced in the conversations between the main characters. Again, the comprehensive God's-Eye View is not merely unavailable to human beings, but there simply is no perspective of that kind; there is no overall explanation or account of how things are. Nevertheless, it is only human to suppose there is, and the whole existence of the powerful figure of Godot is indebted to human belief, imagination and language that fill the silence.

Even language, when trying to reach for metaphysical heights, is drawn from the metaphysical for everyday use in absurd literature. The theatre of the absurd in general approaches the issues of personal guilt and responsibility by showing how the possibility of these concepts becomes obscure or impossible in a modern world. The use of these concepts presupposes an ordered world and meaningful human existence, which are called into question in absurd drama. As Friedrich Dürrenmatt has claimed in his essay "Theaterprobleme" (1955, in Dürrenmatt 1975), tragedy is possible only in an ordered world in which moral causalities take place and human beings bear responsibility for their actions; the tragic world is structured in a meaningful way. In his view, absurd comedy and grotesque are more useful concepts than tragedy in interpreting the current world, since they capture the ambiguous and paradoxical spirit of the age where causalities and personal responsibilities have disappeared and there is no connection to any transcendence. In absurd drama, human life is depicted as completely dissolute of any transcendent realm, and the experiences of meaninglessness and purposelessness stem from this sense of human isolation and dispossession.

While in our earlier work (Kivistö and Pihlström 2016) we studied the Book of Job, Kafka, Beckett, and Orwell for our antitheodicist purposes (suggesting that they interestingly correspond to, or aesthetically manifest, various post-Kantian philosophical antitheodicies), the novels we have now selected as the objects of our closer antitheodicist reading are two works by Joseph Roth. Roth's Hiob: Roman eines einfachen Mannes (1930, Roth 2012) is rather explicitly a rewriting of the Book of Job. The novel tells us a story of a simple man, whose life becomes special through his extraordinary suffering. The protagonist of the novel, Mendel Singer, relives the destiny of Job as his later incarnation and as if in a sort of textual possession that he cannot leave behind. We could talk about Job's existential 
immediacy in Roth's work that determines Mendel Singer's life course. ${ }^{10}$ As is characteristic of Roth's writings, the first setting of the novel describes a rather fixed framework. The protagonist Mendel Singer is an ordinary, honest man who lives a happy life with his wife and children:

He was pious, godfearing, and ordinary, an entirely commonplace Jew. He practiced the simple profession of a teacher. In his house, which was merely a roomy kitchen, he instructed children in the knowledge of the Bible. He taught with honourable zeal and without notable success. Hundreds of thousands before him had lived and taught as he did. (Roth 2012, p. 9; quoted in English in Fisch 1998, p. 104)

Soon after these initial notes that emphasize the hero's ordinary life, the situation suddenly changes and the stable framework collapses through a series of misfortunes. In the manner of other rewritings of the Book of Job, the novel is closely connected with the literary tradition that investigates the overwhelming reality of innocent and pointless suffering. It describes a situation in which the protagonist tries to reach for apparent meaning amidst a human life that is deeply unfair. His youngest son is seriously retarded, and the father tries to get into some contact with his son:

He [Mendel] tried to guess what might be going on in that broad skull, to gaze in through the eyes as through a window in the brain, and by talking to him, sometimes loudly, sometimes softly, to draw from the stolid boy some sort of sign. He would repeat Menuchim's name ten times, moving his lips slowly so that the boy could see him say it if he could not hear. But Menuchim never responded.

Then Mendel would take a spoon, strike it against a tea-glass, and immediately Menuchim would turn his head, and a tiny light would flame on his great, grey, liquid eyes. [ ... ]

"Why am I so afflicted?" thought Mendel, and he explored his conscience for sins but found none that was grave. (Roth 2012, pp. 45-46; quoted in English in Fisch 1998, p. 105; emphasis added)

Mendel here affirms his innocence and presents the essential question regarding the pointlessness of his existence and suffering (Why? Why Me?), and this is only one occasion that resembles the example of Job in the novel. Among the numerous disasters Singer has to face are the death of his wife and the demise of his children. ${ }^{11}$ Travelling to America brings yet another disappointment to Mendel Singer's life, since he had hoped that America would offer an escape for his family (and for humankind) from the existential crisis, but these utopian hopes are never fulfilled. At this point Mendel turns to a rebellion against God: "His heart was angry against God, but in his sinews the fear of God still dwelt". Singer is not denying God but confronting him, and he refuses to pray: "I shall not pray,' thought Mendel" (quoted in Fisch 1998, p. 107). His friends also explicitly compare him with Job. Roth's long account of irrational and constant agony creates a world without any moral balance that would guarantee that people receive what they deserve, and without any principle that would order that offenders are punished and the innocent stay free. As Hans Küng remarks in his essay "Religion in the Controversy over the End of Religion," "in suffering, especially in that of the innocent, man comes up against his extreme limit, comes to the decisive question of his identity, of the sense and nonsense

10 On Roth's rewritings of Job, see (Hasan-Rokem 2015; Fisch 1998).

11 This experience of radical disorder and despair also reminds one of Dostoevsky's Ivan Karamazov who is among the most famous similar descendants of Job, who returns his entrance ticket to heaven to God, not because he would not believe in God but because he cannot accept the unfair world God has created, longing for justice in the existing human world and not in some remote time to come, and morally refusing to accept any imaginable future reconciliation as a justification for innocent suffering. Posthumous glory and rewards in the afterlife are not something Ivan would be looking for, and the rosy promise of heaven is not satisfactory to him in a world in which innocent children suffer, since theodicy and future harmony simply collapse in the face of these victims. Ivan is not an atheist in any ordinary or straightforward sense; Dostoevsky called him deep, because he refuses to accept cheap solutions or consolations. 
of his living and dying, indeed, of reality pure and simple" (Küng 1991, p. 234). Mental simplicity that appears in the subtitle of the novel can be read as a moral ideal stemming from the early (Hebrew) religion and thought, thus challenging overly rationalist perspectives on religion and suffering offered, for instance, by theodicy.

Roth's earlier novel, Die Rebellion (1924, Roth 2010), is another fictitious exploration of the problem of innocent suffering. Its main character Andreas Pum is a former soldier who has lost his leg in the war, but despite this major personal sacrifice he still believes in the sacred moral order of the world. At the beginning of the novel, Andreas is irritated by his comrades who complain and curse their future, as if they did not deserve their condition, but in Andreas's view all the suffering is likely to be necessary for some overall good. Andreas believes in a just god and some kind of business contract with Him, whereby He gives medals to those who have suffered in the war, and he rationalizes that the loss of one leg is not that bad if you get something better for compensation, as "the joy of receiving a medal was considerable" and "an invalid might enjoy the respect of the world" (p. 2). Pum believes not only in the justice of God, but also in the unfailing protection and support of the government that "overlies man as the sky overlies earth" (p. 2). The government represents here another fallacious overwhelming force that is the object of Pum's naïve expectation of a rationally ordered cosmos: "What comes from it may be good or ill, but it cannot be other than great and all-powerful, unknowable and mysterious, even though on occasion it may be understood by an ordinary person" (p. 2).

Instead of receiving an artificial leg, a medal, or a state employment for his services and sacrifices to his country, Andreas faces only unrest and upheaval. He becomes involved in a small scuffle that, in the manner of tragedies, leads to unexpected and disproportionate consequences and to a trial that sends him to prison. The sudden arrest, the legal process, and the trial scenes remind one of Kafka's missing legal order, and the little yellow church that Andreas visits for prayer also echoes the Kafkaesque silence of the gods; the church is empty and the winter sends its chilly breath into the house of God, which smells of snuffed candles that no longer give light. During all the distress, Andreas finally gives up his faith in a just world and questions God's goodness. While in prison he doubts whether God will look after the birds when he apparently does not care about the human beings; on the contrary, he punishes the innocent with suffering for no apparent reason. In the manner of Job, Andreas tries to examine hidden sins within his soul, with the idea that perhaps God knows some secret sin within him that he himself is not aware of, but he finds none that would be grave, and his worship changes into a rebellion against the world, its authorities, and God. He loses his belief in an inherent order that was grounded in his faith in God and the government.

The novel includes many elements that are familiar from the Book of Job and its later imitations, such as the self-examination of sins and the gradual awakening to the fact that the world is not governed by any moral balance or great justice that would reward loyalty and suffering with praise and honors. While nothing turns up to explain or reward the suffering, the protagonist finally starts to rebel against God. While in the beginning Andreas still claims that his own conscience is as clean as the china plate that is struck by a sunbeam as if by a check mark from Heaven (the symbol refers to some providential causality or presence in the world), he gradually loses his belief in such meaningful details and signs from transcendence as these turn out to be his own fantasies. The surrounding people and public authorities of society typically view his shortcomings from an objectifying perspective and nobody is engaged with or cares about his case. The officials love order and norms in various forms, and they objectify Andreas's case as a legal process independent of ethical considerations, whereas Andreas no longer assumes any social order and concludes that the world is much more complicated than any simple plot lines would suggest. There is no simple punishment and reward pattern according to which one could expect compensation for one's sacrifices or whereby everyone could achieve their own luck according to their merits; the world is governed by random luck alone. It is noteworthy that, in the manner of tragedies, the world continues its normal course regardless of the hero's collapse; it does not affect the broader picture or the life of the other people of the novel at 
all. In the end, Andreas's former friend and employer starts to look for another old soldier to take care of the dead man's duties as a lavatory attendant.

Unlike in Kafka's novels, which are full of meaningless details and whose atmosphere is dominated by the sense of pointless existence, in Roth's Hiob there is at least an apparent divine plot or purpose to the course of events (see also Fisch 1998, p. 108). There are channels of communication between the divine and the human (the prophecy in the beginning and the redemption at the end), and some finality (with an intention) in the form of the fairytale-like happy ending. Menuchim fulfills the prediction presented by a rabbi in the beginning of the novel, as he is made stronger through his suffering and finally healed. "The listening light" in Menuchim's eyes (see the quotation above) becomes meaningful in the story, anticipating the concluding miracle: Menuchim Singer has become a musical star (thus embodying the family name) and comes to meet his father in the final redemption scene. The unexpected turn of the plot seems to suggest that there is some final good in human life, but the harmonious conclusion is deeply ambiguous. On the one hand, it seems to offer the interpretative possibility that the true religious essence lies in the sense of mystery, and that finally all suffering receives its compensation, just like there is a happy ending in the Book of Job in which all Job's goods are restored. On the other hand, this (theodicist) understanding of the fairytale-like ending is not the only possible interpretation, since the unexpected turn brings yet another unpredictable element to the world that does not follow any patterns of justice or predictability. The sudden happy ending may feel unsatisfactory and disappointing precisely because it offers an unlikely and implausible conclusion to the novel, an ironic deus ex machina that seems to underline not so much the happy redemption but rather the fact that human suffering is not resolved in this world but only in some fictitious heaven that is also described in the end of Die Rebellion; only there is the protagonist finally able to meet his God and present his accusations against him. The human world remains deeply unjust and its problems remain unsolved, despite the happy ending and harmonious total picture that feel merely far-fetched when compared with all the preceding malaise.

Roth's Hiob thus also subverts the basic assumption of literary realism that the fictional reality rests on some intrinsic order. The sudden ending ironically underlines that it is not some cosmic force that creates and maintains meaningful order in the world; if there exists some chain of events or apparent mimetic order in the world, this order is completely fictitious and imposed on a chaotic world. Roth thus also challenges the basic idea of realism and the typical teleological plot of a realist novel, in which the fictional world usually follows an inevitable and irreversible cause-and-effect order of events. In realist novels, the immutable order usually remains, but here the seemingly simplistic fairytale ending complicates the picture by challenging the conventional intrinsic order characteristic of literary realism and privileging contingency over superimposed causality. ${ }^{12}$ At the same time, this challenge to literary realism is-if our antitheodicist reading is correct-a challenge to philosophical (metaphysical) realism, insofar as the latter is presupposed by the theodicism that these rewritings of Job's story can be read as criticizing.

We will not go into further readings here, but we can briefly note that yet another, more recent novel that very interestingly complicates the simple punishment or reward model (defended by Job's friends, for example) is Philip Roth's Nemesis (Roth 2010). Its main character Bucky Cantor (yet another "singer") is a gym teacher who suffers from bad eyesight and some vague sense of shame owing to his physical weakness. In the main plot he fights against a sudden spread of polio, until he realizes that he has been spreading the infection himself. The virus has followed him from his school to the summer camp and more children are infected. In this sense the novel resembles a Greek tragedy, as the protagonist tries by all means to avoid the inevitable disaster but merely manages to advance the unhappy turn and cause more suffering. Like Oedipus, Cantor is ignorant of his guilt, but still guilty of

12 On the tensions between realism and modernism in Roth's Radetzkymarsch, see (Landwehr 2003). 
the disaster and the epidemic that infected his community; his lot is tragic, but not unfair, whereas Job was completely innocent. ${ }^{13}$

Cantor holds God accountable for all the suffering and looks for a deeper cause, while failing to grasp the broader picture. He accuses God of creating the virus and causing the deaths of innocent children: "His anger was provoked-not against whatever cause, however unlikely, people, in their fear and confusion, might advance to explain the epidemic, not even against the polio virus, but against the source, the creator-against God, who made the virus" (p. 127). He has serious difficulties in understanding the meaning of suffering and he also presents the ponderous why question familiar from other narratives of unmerited suffering: "Why does He set one person down in Nazi-occupied Europe with a rifle in his hands and the other in the Indian Hill dining lodge in front of a plate of macaroni and cheese? Why does He place one Weequahic child in polio-ridden Newark for the summer and another in the splendid sanctuary of the Poconos?" (p. 154) — "Why didn't God answer the prayers of Alan Michaels's parents? They must have prayed. Herbie Steinmark's parents must have prayed. They're good people. They're good Jews. Why didn't God intervene for them? Why didn't He save their boys?"(p. 170).

Job's opponents were his friends, but here the opponents are Bucky's naïve girlfriend, who advises him to seek relief in prayer, and the narrator, who turns out to be a former polio patient called Arnie (see also Batnitzky 2015, p. 220). He represents a secularist (or an atheist) view of life, stressing that one's life course is contingent and Bucky's stubborn posing of the why question is mindless, since Bucky should accept the tragic meaninglessness of suffering and not try "to convert tragedy into guilt" or "to find a necessity for what happens" (p. 265). But Bucky resembles Job in that he openly accuses God and sincerely tries to capture the sense of the suffering, yet without finding any overall picture. He speaks aloud and insists that his question must be heard and answered, but God remains silent.

In their different ways, all these literary examinations of antitheodicist thinking can be seen as presenting an essentially moral argument against theodicism, based on the idea that theodicies fail to adequately recognize the meaninglessness of individuals' suffering and typically (as a result of that non-acknowledgment) treat suffering human beings as mere means to some alleged overall good, thus also subordinating the suffering individual to some totalizing framework. Furthermore, there is an aesthetic dimension to this totalizing attempt. The aesthetics of antitheodicy, we might say, is an aesthetics of disharmony: the literary narratives briefly explored here can show that there may be no final harmonious justification, accommodation, or meaningfulness of evil and suffering, or, if there is, it is emphatically fictitious, as in Joseph Roth's novels. The world is not neat and harmonious: there is real evil, misery, suffering, and non-totalizable otherness. Disharmony is a central aesthetic category in all the literary works studied here. Job does not get any moral explanation from God but only a picture of a cruel, amoral creation; Josef K. finds no explanation for his case and never learns to know the actual reasons for his unexpected arrest. Beckett's tramps seem to live in a world that lacks meaning altogether.

If Beckett ridiculed the futile search for a rational universe, Joseph Roth took this quest more seriously. In Roth's novels, there is the assumption of there being an absolute super-perspective (a God's-Eye View), although it is unavailable to the protagonist, but it is a perspective of absoluteness that unethically neglects or reduces the significance of the protagonists' first-person individual human perspectives. There is a clash between the anthropocentric and the theocentric perspectives there, whereas in Beckett's Godot the very existence of such a super-perspective is suggested to be fundamentally illusory. Beckett shows us how human beings struggle in vain to find such a perspective, which simply is not there at all. There is no overall account of how things are; as suggested above,

13 On Joban (tragic) themes in Roth's Nemesis, see (Batnitzky 2015). 
it is only a human (and perhaps humanly understandable or even unavoidable) temptation or tendency to suppose there is, or to hope one could achieve such a perspective.

The literary works that deliberately elaborate on the Book of Job crucially contribute to the understanding of the problem of suffering that is at the heart of the theodicism versus antitheodicism controversy. What these works also illustrate is that disharmony also means multiple individual voices: the ethics and aesthetics of antitheodicy cannot be reduced to an overarching voice or an overall picture that would provide a single perspective on the world. In this sense, the rejection of metaphysical realism and the God's-Eye View exemplified by the antitheodicist literature studied here is also aesthetic.

\section{Recognition, Theory, and Practice}

Acknowledging reality-whatever we mean by that vague phrase-though necessary for adequate ethical acknowledgment of others' suffering, does not require metaphysical realism. On the contrary, metaphysical realism itself fails to acknowledge reality in its diversity, as it reductively objectifies everything into a single picture (as we have suggested). What proper acknowledgment requires is just a commitment to objective truth in an ordinary, philosophically unelaborated sense (see Section 2 above) rather than any overall assumption of metaphysical realism. Theodicies are of course only one specific, albeit ethically highly influential, example of a distorted non-acknowledgment of reality. Others include a quasi-Orwellian (or, perhaps today, "Trumpist") failure to acknowledge the very significance of truth and facts (as witnessed by the horrifyingly Orwellian pseudo-discourse of "alternative facts"), as well as popular self-help literature advancing various manipulative pseudo-therapies, self-branding, etc. There are profoundly problematic elements of insincerity in such cultural phenomena that are in interesting ways analogous to theodicist narratives with their postulation of a harmonious total picture. What we need as a remedy is not metaphysical realism with its imagined super-absolute facts but an ethical acknowledgment of humanly constituted and reconstructed reality and objectivity. It is part of this acknowledgment to also acknowledge the essentially contestable nature of any facts we may be committed to as well as the fragility of any meanings and meaningfulness we may find in our world. ${ }^{14}$ When Richard Rorty (1989) tells us that if we take care of freedom, truth can take care of itself, ${ }^{15}$ he needs to be reminded that this is true only if freedom is not just negative freedom from constraints but positive freedom that includes responsibility and a genuine commitment to acknowledgment, including the acknowledgment of human suffering, finitude, and fragility.

We have suggested that the realism discussion in the philosophy of religion, while apparently independent of the theodicy discussion, is actually very closely tied to the latter-to the extent that theodicism (typically, paradigmatically) presupposes a problematic form of metaphysical realism and should be criticized along with such realism. We have also suggested that antitheodicist literary works challenging literary realism can be read as also criticizing this philosophical form of realism. The collapse of metaphysical realism hardly directly entails the collapse of theodicism, but the antitheodicist should focus on attacking the metaphysically realist background assumptions of theodicism in addition to focusing on the main task of showing the colossal failure of moral acknowledgment in all attempts to justify others' suffering. This task can also be formulated in terms of the concept of truth. While metaphysical realism and theodicies seek the objective, absolute, and general truth—from a God's-Eye View-about suffering and its reasons, this search

14 It can be suggested that if evil indeed is part of God's good creation, then the theodicy problem does not even arise, as its presuppositions are not fulfilled: it cannot even be coherently posed, because everything, as created by God, is by definition meaningful. (We are indebted to Akeel Bilgrami for this formulation.) The antitheodicist criticism of theodicies can also focus on the very availability of the theodicy problem in this sense-and on the assumption that there must be (somewhere) the kind of meaning postulated by theodicies.

15 This remark, in the context of Rorty's reading of Orwell, is commented on in more detail in (Kivistö and Pihlström 2016, chp. 5). (See also Conant 2000; Rorty 2000.) 
(we have argued) incorporates a failure to acknowledge the perspectival diversity of individual suffering and hence an inability to capture all the relevant truths that ethically demand our attention. A more perspectival pragmatic conception of truth is therefore to be preferred, for ethical reasons, to metaphysically realist correspondence truth (cf., e.g., Pihlström 2013).

The theodicy vs. antitheodicy issue is often seen as purely metaphysical (as in Leibnizian theodicies and their contemporary variants) or, alternatively, as primarily ethical (as in "moral antitheodicism" based on, say, Levinasian criticism of the immorality of justifying others' suffering, a criticism that claims to be more fundamental than any metaphysical theorization). We have tried to argue, at least implicitly, that both are too narrow ways of conceiving the matter. The issue we are dealing with actually exemplifies the deep entanglement of the moral and the metaphysical (as well as the aesthetic). One way to see the entanglement at the core of this topic is to note how deeply theodicies are committed to metaphysical realism. Antitheodicism, as has been suggested, is based on the ethical affirmation of the fundamental need to recognize or acknowledge-ontologically as well as ethically-individual sufferers' (or victims' of evil) perspectives in their distinctiveness and irreducibility. This requires that we reject metaphysical realism as a non-recognizing (and therefore at least potentially even morally corrupting) totalizing attempt to view the world as a totality from a God's-Eye View. This rejection is both ethical and metaphysical, with the two aspects inseparably present. Not only are the ethical and the metaphysical entangled here; similarly (and entangled with this entanglement), there is the entanglement of the unintelligibility or incoherence, on the one hand, and the ethical unacceptability, on the other, of the kind of metaphysics invoked by theodicies, based on metaphysical realism.

It could also be suggested that if metaphysical realism and thereby theodicism really are incoherent responses to the reality of suffering (or to reality generally), then we could not really be theodicists even if we tried. We would be in "bad faith"; we would in reality always already have acknowledged the moral status of the other person and thus also the irreducibility and unobjectifiability of their suffering, simply as a necessary precondition for our own moral subjectivity, and therefore the theodicy argumentation could not really get off the ground at all. ${ }^{16}$ An engagement in theodicies, or a commitment to theodicism, would thus in a way be a self-denial, a concealment of one's inevitable commitment to moral acknowledgment. We may agree with this suggestion while also maintaining that it is important to emphasize the incoherence of theodicist and metaphysically realist thinking. Kant had to write hundreds of pages in defense of transcendental idealism while also maintaining that in some sense anyone who has experiences of objective objects and events must be a transcendental idealist (even against their own will), as its alternative transcendental realism is ultimately incoherent.

There is one more issue we need to deal with. A typical response to moral criticisms of theodicies in contemporary mainstream analytic philosophy of religion pursuing theodicies (or "defenses") starts from a sharp distinction between theory and practice. Theodicists can easily maintain that at the theoretical level their justifications for evil and suffering (or, more modestly, the defense according to which God might, for all we know, have acceptable moral reasons that would justify his allowing the world to contain apparently meaningless evil and suffering) may indeed fail to recognize the suffering other, or their experiences of meaningless suffering, while also maintaining that such a failure — based on (they might admit) metaphysical realism, as we have argued—does not matter philosophically or ethically insofar as the theodicist exercise indeed is, and remains, merely theoretical. Theodicists can (and arguably should) still avoid engaging in their theory-construction (backed up by metaphysical realism) when actually faced by suffering human beings and the practical need to comfort them. This practical task of consolation is to be clearly distinguished from the purely theoretical or intellectual task of constructing a theodicy argument or a "defense".

16 We are here indebted to a suggestion made by Steven Crowell in relation to a related paper. Crowell formulated this as a Levinasian rejoinder to the kinds of worries raised here. 
For example, Peter Van Inwagen (2006, p. 12) tells us that his examination of the problem of evil is "purely intellectual" and that his "defense" is not intended to even hypothetically comfort anyone (Van Inwagen 2006, p. 108); similar caveats are added by a number of other theodicists. Hence, it could be claimed that no failure of recognition is necessarily committed by the theodicist (or the one who seeks to offer a "defense") at the practical level of engaging with suffering human beings needing consolation (or, in a theological context, pastoral care). If the distinction between theory and practice is drawn carefully enough, theodicies and defenses may remain purely theoretical and intellectual, while comfort and consolation are practical matters to be dealt with separately.

However, it can now be argued-for example, from a pragmatist point of view (cf. Pihlström 2013, 2014), though this line of argument is certainly not restricted to pragmatism - that the very attempt to defend theodicism by drawing such a sharp theory-practice dichotomy itself (at a meta-level) constitutes a moral failure of recognition. The suffering other ought to be morally recognized precisely by not drawing such a dichotomy-that is, by not engaging in the theoretical argumentative exchange of purely intellectual ideas pro and contra theodicies at all. This, we may say, is where the metaphilosophical relevance of moral antitheodicism for the pursuit of philosophy of religion primarily lies. Again, antitheodicist arguments and positions as diverse as James's pragmatism, Phillips's Wittgensteinianism, and Levinas's insistence on the primacy of the other's face can be regarded as variations on this general theme, and so can the antitheodicist readings of the literature presented in the previous section. James (1907, James 1975, chp. 1) seems to base his entire pragmatic method on an antitheodicist refusal to attach any absolute or abstract metaphysical significance (either Hegelian or Leibnizian) to individual experiences of concrete suffering, while Phillips (2004) warns against the morally corrupting language of anthropomorphic accounts of God that seem to turn God into a monstrous agent calculating the advantages and disadvantages of allowing his creation to suffer. In a different but arguably analogously pragmatic strain, Levinas (2006) maintains that the justification of others' suffering is the foundation of all immorality. In their distinctive ways, these antitheodicist thinkers suggest that there is something deeply wrong — and non-recognizingin the theory-practice dichotomy itself in this area.

It can be further argued that antitheodicism (exemplified by these very different thinkers), in insisting on not explaining away the meaninglessness of suffering, is needed precisely as a necessary condition for the possibility of adequately recognizing the other person as a (potential or actual) sufferer. It can be part of that adequate recognition to acknowledge that there is suffering that simply cannot be rendered meaningful in any morally acceptable sense. Therefore, there is a sense in which theodicist attitudes to others should not themselves be (philosophically, ethically) recognized as ethically appropriate attitudes, or perhaps not even tolerated, and this rejection of theodicism can be articulated in terms of pragmatism that is generally critical of any principled theory-practice dichotomies. If theory and practice are inevitably entangled, then the failure to recognize this entanglement again constitutes a failure to adequately engage in the practical task of recognizing otherness.

\section{Concluding Reflections}

It should thus be re-emphasized that a philosophical opposition to metaphysical realism, to reductive objectification, to what Kant called transcendental realism, and to various forms of reductionism and totalizing, on the one hand, and antitheodicism acknowledging individual suffering in its perspectival variety (defended in the literary works examined above, and in contrast to theodicist postulations of a totalizing overall perspective), on the other hand, are really two sides of the same coin. However, we should recognize a final reflexive problem here. Are we saying that this antitheodicism is a generally correct view to embrace? Are we betraying our own defense of irreducible perspectivalness, and the respect for diversity that goes along with it by failing to recognize the philosophical value of, say, monism and reductionism-or, indeed, of theodicism? We have no final answer to provide here. We are just tempted to point out that this criticism amounts to something comparable to the 
claim that one should, if one is tolerant, also tolerate intolerance; the only possible response to such a criticism in the end is "no, one should not." Yet, we should constantly examine our own temptations to reductionism, theodicism, and non-recognition.

The fact that we have to be reflectively self-critical in our pursuit of antitheodicism yields one final comment on what we might call the humanism of antitheodicism. ${ }^{17}$ We should defend the individual human being's right and duty to take responsibility for creating moral meaning into her/his life and the world s/he lives in, in the absence of any transcendent, metaphysico-theological or theodicist grand narratives of the meaningfulness or significance of suffering. This is something that our reading of antitheodicist literature brings out very clearly. The human being stands in the center of this ethical project of constructing meaning; this is a human existential task that cannot be handed over to any (real or imagined) God. "Creating moral meaning" does not amount to discovering any ready-made meanings or moral truths (in a metaphysically realistic sense) but to living an open, possibly very difficult life fully aware of the significance of what Wittgenstein in the Tractatus (1921) called the "problem of life." Such creation of meaning may crucially need literary and other artistic perspectives on the world we live in. While fictional literature can hardly directly provide a knock-down argument against metaphysical realism or theodicism, it may be an essential, undetachable element of a sufficiently rich philosophical consideration of these issues—or so, at least, we have tried to suggest in this paper.

This "humanism of antitheodicism" is also, arguably, a humanism of a "de-selfing," disappearing subject: the ethically engaged person does not set her-/himself at the center but disappears into the world like the metaphysical subject of Wittgenstein's famous (albeit extremely controversial) solipsism in the Tractatus (Wittgenstein 1974, § 5.64; cf. Pihlström 2016, chp. 3). Such humanism is very different from the way in which the human being (one's own self) is placed at the center of things in contemporary popular "selfie" and self-help culture. The self-critically reflective antitheodicism we have defended in this paper contains the requirement of constant vigilance in not setting oneself first and thereby failing to recognize others' suffering. This is why it is important to fight against one's own theodicist temptations-and the related temptation to embrace the only apparently consoling absolute picture of metaphysical realism. Our criticism of theodicism and non-acknowledgment should first and foremost be self-criticism. Reading (and writing) creative literature drawing attention to others' suffering may be a fundamental element of such a campaign.

Acknowledgments: We are particularly grateful to Simo Knuuttila, Heikki J. Koskinen, Panu-Matti Pöykkö, and Risto Saarinen for helpful conversations on the topic of this paper. Thanks are also due to Jill Hernandez for her invitation to submit this paper to this special issue, as well as to the anonymous reviewer for helpful comments. We also gratefully recognize the significance of the Academy of Finland Centre of Excellence, "Reason and Religious Recognition" (hosted by the Faculty of Theology, University of Helsinki) for our work.

Author Contributions: The authors are jointly responsible for the entire article, though the literary sections were primarily written by Sari Kivistö and the philosophical sections by Sami Pihlström.

Conflicts of Interest: The authors declare no conflict of interest.

\section{References}

Batnitzky, Leora. 2015. Beyond Theodicy? Joban Themes in Philip Roth's Nemesis. In The Book of Job: Aesthetics, Ethics, Hermeneutics. Edited by Ilana Pardes and Leora Batnitzky. Berlin: De Gruyter, pp. 213-24.

Beckett, Samuel. 2006. The Complete Dramatic Works. London: Faber and Faber.

Bernstein, Richard. 2002. Radical Evil: A Philosophical Interrogation. Cambridge: Polity Press.

Betenson, Toby. 2016. Anti-Theodicy. Philosophy Compass 11: 56-65. [CrossRef]

Byrne, Peter. 2003. God and Realism. Aldershot: Ashgate.

17 This fundamental humanism can, again, be regarded as a common feature shared by the different antitheodicisms briefly mentioned above. It should come as no surprise that such humanism is a trend in antitheodicisms that can be taken to be "Kantian" (cf. again Kivistö and Pihlström 2016), given Kant's insistence on the irreducible value of the human person. 
Carson, Thomas L. 2007. Axiology, Realism, and the Problem of Evil. Philosophy and Phenomenological Research 75: 349-68. [CrossRef]

Conant, James. 2000. Freedom, Cruelty, and Truth: Rorty versus Orwell. In Rorty and His Critics. Edited by Robert B. Brandom. Oxford and Cambridge: Blackwell, pp. 268-342.

Dürrenmatt, Friedrich. 1975. Der Besuch der alten Dame. Stuttgart: Reclam.

Fisch, Harold. 1998. New Stories for Old: Biblical Patterns in the Novel. Basingstoke: Palgrave Macmillan.

Habermas, Jürgen. 2010. An Awareness of What Is Missing. Cambridge: Polity Press.

Hasan-Rokem, Galit. 2015. Joban Transformations of the Wandering Jew in Joseph Roth's Hiob and Der Leviathan. In The Book of Job: Aesthetics, Ethics, Hermeneutics. Edited by Ilana Pardes and Leora Batnitzky. Berlin: De Gruyter, pp. 147-71.

James, William. 1975. Pragmatism: A New Name for Some Old Ways of Thinking. Edited by Frederick H. Burkhardt, Fredson Bowers and Ignas K. Skrupskelis. Cambridge and London: Harvard University Press. First published 1907.

Kafka, Franz. 1955. The Trial. Translated by Willa and Edwin Muir. London: Penguin. First published 1925.

Kant, Immanuel. 1983. Über das Misslingen aller philosophischen Versuche einer Theodicee. In Werke in zehn Bänden. Edited by Wilhelm Weischedel. Darmstadt: Wissenschaftliche Buchgesellschaft, vol. 9. First published 1791.

Kivistö, Sari, and Sami Pihlström. 2016. Kantian Antitheodicy: Philosophical and Literary Varieties. Basingstoke: Palgrave Macmillan.

Küng, Hans. 1991. Religion in the Controversy over the End of Religion. In Literature E Religion. Edited by Walter Jens and Hans Küng. New York: Paragon House.

Landwehr, Margarete Johanna. 2003. Modernist Aesthetics in Joseph Roth's Radetzkymarsch: The Crisis of Meaning and the Role of the Reader. German Quarterly 76: 398-410. [CrossRef]

Levinas, Emmanuel. 2006. Entre-Nous: Thinking-of-the-Other. Translated by Michael B. Smith. London: Continuum.

Neiman, Susan. 2002. Evil in Modern Thought: An Alternative History of Philosophy. Princeton: Princeton University Press.

Newsom, Carol A. 2009. The Book of Job: A Contest of Moral Imaginations. Oxford: Oxford University Press.

Phillips, Dewi Zephaniah. 2004. The Problem of Evil and the Problem of God. London: SCM Publications.

Pihlström, Sami. 2013. Pragmatic Pluralism and the Problem of God. New York: Fordham University Press.

Pihlström, Sami. 2014. Taking Evil Seriously. Basingstoke: Palgrave Pivot.

Pihlström, Sami. 2016. Death and Finitude: Toward a Pragmatic Transcendental Anthropology of Human Limits and Mortality. Lanham: Lexington Books.

Rorty, Richard. 1989. The Last Intellectual in Europe: Orwell on Cruelty. In Contingency, Irony, and Solidarity. Cambridge: Cambridge University Press.

Rorty, Richard. 2000. Response to James Conant. In Rorty and His Critics. Edited by Robert B. Brandom. Malden and Oxford: Blackwell, pp. 342-50.

Roth, Joseph. 2010. Rebellion. Translated by Michael Hoffman. New York: Picador. First published 1924.

Roth, Joseph. 2012. Hiob. Roman.. Köln: Kiepenheuer \& Witsch. First published 1930.

Roth, Philip. 2010. Nemesis. London: Vintage.

Rowe, William, ed. 2001. God and the Problem of Evil. Malden and Oxford: Blackwell.

Saarinen, Risto. 2016. Recognition and Religion: A Historical and Systematic Study. Oxford: Oxford University Press. Van Inwagen, Peter. 2006. The Problem of Evil. Oxford: Clarendon Press.

Wittgenstein, Ludwig. 1974. Tractatus Logico-Philosophicus. Translated by Brian F. McGuinness and David F. Pears. London: Routledge and Kegan Paul. First published 1921.

(C) 2017 by the authors. Licensee MDPI, Basel, Switzerland. This article is an open access article distributed under the terms and conditions of the Creative Commons Attribution (CC BY) license (http:/ / creativecommons.org/licenses/by/4.0/). 